\title{
GRUNWALD W TRADYCJI KAZNODZIEJSKO-KRONIKARSKIEJ Z KOÑCA XV WIEKU
}

Sławne zwycięstwo grunwaldzkie z r. 1410 znalazło współcześnie swoje odbicie nie tylko w piśmiennictwie historyczno-politycznym, lecz także w tekstach kaznodziejskich. Religijnym podłożem była tu okoliczność odniesienia tego zwycięstwa przez armię polską pod dowództwem Władysława Jagiełły w dniu święta Rozesłania apostołów (15 lipca). Odtąd jako wyraz szczególnej wdzięczności za doznaną łaskę opieki Bożej uroczyście obchodzono w Polsce to święto. Z tej okazji wygłaszane były okolicznościowe kazania. Niektóre z nich zachowały się w kolekcjach kazań de sanctis polskich autorów, a także oddzielnie.

Historię tego święta w Polsce przedstawił z prawdziwym znawstwem ks. Jerzy Wolny ${ }^{1}$. Uznał on fakt podniesienia rangi teg.o święta za ,,pierwszy wypadek wprowadzenia do kalendarza kościelnego rocznicy politycznej", zaznaczając, że ,tym samym ustanowiono pierwsze święto narodowe w Polsce". Przypomniał też relację Jana Długosza ${ }^{2}$ o tym święcie:

Sancitum autem tunc [a. 1411] fuit et universali decreto a Wladislao rege et omnibus statibus ecclesiasticis et secularibus concordi sentencia et consensu institutum ut Divisionis Apostolorum dies solennis agatur, et feriata in universo Poloniae regno celebretur doceantque patres suos filios, nepotes, pronepotes et successores ut diem illum observent colantque memoria sempiterna, in qua benignitas Dei misericordiam suam cum Polonorum natione et stirpe magnificasset et ut singulae ecclesiae tam urbanae quam vicanae per universum Poloniae Regnum constitutae et celebritate singulari et missarum processionumque officii diem tanti triumphi cum plebibus suis recolant et agant ingentes Deo pro beneficio Polonorum genti impenso gratiarum actiones.

W przytoczonym artykule ks. Wolny cytuje z wykazu świąt diecezji krakowskiej z r. 1396 marginalny dopisek ${ }^{\mathbf{3}}$ :

Divisionis dies apostolorum ecclesia, clerus et vulgus solempniter, tamquam festum triumphi et victorie Polonorum, per totum regnum Poloniae et cum magna devocione celebrent.

1 J. Wolny, Kaznodziejstwo, [w:] Dzieje teologii katolickiej w Polsce, t. 1: Sredniowiecze, Lublin 1974, s. 291 n.

2 Ioannes Długosz, Historia Polonica, t. 4, Cracoviae 1877, s. 127.

${ }^{3}$ Rkps Biblioteki Książąt Czartoryskich w Krakowie nr 1440 s. 601. 
Wymienia przy tym kilka kazań na Rozesłanie apostołów między nimi wydane poniżej, występujące w rękopisie Biblioteki OO. Paulinów, na Skałce w Krakowie (sygn. B 23). W zbiorze kazań Mikołaja z Błonia, dekretysty, kanonika płockiego i kapelana królewskiego, zmarłego przed r. 1448, zachowały się dwa kazania na święto Rozesłania apostołów. Duży ich fragment, dotyczący m. in. bitwy pod Grunwaldem i śmierci Władysława Jagiełły, wydał Ernest Strehlke ${ }^{4}$.

Poniżej omawiam i publikuję drukiem dwa kazania de divisione apostolorum, pochodzące $\mathrm{z} X \mathrm{XV}$ wieku. Pierwsze znajduje się $\mathrm{w}$ zbiorach Biblioteki Jagiellońskiej (rkps przyb. 2/84). W roku 1984 Biblioteka Jagiellońska zakupiła $\mathrm{z}$ prywatnych rąk kodeks kaznodziejski $\mathrm{z}$ drugiej połowy XV w. W r. 1678 wraz z calym księgozbiorem został on ofiarowany przez Chryzostoma Bodzętę, kanonika katedry krakowskiej, kamedułom na Bielanach w Krakowie. Dużą część tego obszernego, liczącego około 350 kart rękopisu papierowego in quatro, stanowią nieznane pasje i kazania postne oraz o Męce Pańskiej. Wyszły one prawdopodobnie spod pióra autorów polskich (na k. 10v cytowany jest Jan ze Słupczy). Wartość naukową kazań podnosi duża ilość glos polskich, wtrąconych w teksty łacińskie a nie występujących w Słowniku staropolskim. W tej części kodeksu znajduje się anonimowe kazanie, a raczej materiały do niego na temat „Thoma, quia vidisti me credidisti” (f. 94r-98r). Na podstawie filigranu występującego $\mathrm{w}$ składce można postawić tezę, że kazanie to zostało napisane około r. $1470^{5}$. Natomiast od f. $135 \mathrm{r}$ w rękopisie znajduja się kazania de sanctis z Exemplar salutis aeternae Hieronima Jana Sylvanusa z Pragi.

Autor kazania „Thoma, quia vidisti me credidisti" dowodzi, że apostołowie, którzy zostali posłani do wszystkich ludzi, aby ich zbierać w jednej wierze, otrzymali od Chrystusa moc czynienia cudów i znaków. Wtedy były one konieczne, aby uwierzono i przyjęto trudną do zrozumienia naukę Chrystusową. Obecnie, mówi kaznodzieja, gdy wiara jest już dostatecznie potwierdzona przez cuda Chrystusa i apostołów, te cudowne znaki są już niepotrzebne. Jednak w czasie wielkiej wojny, toczącej się na terenie Prus, Chrystus za przyczyną apostołów sprawił wielki cud. Gdy bowiem zakonnicy i Krzyżacy chcieli usunąc ze świata język polski, On nas osłonil i wyrwał z ich rąk. Rozproszył dumnych, a nas obronił przed icho złością. Po tym akcencie politycznym kaznodzieja mówi o tym, kiedy apostołowie zostali rozesłani, dlaczego było ich dwunastu i kto symbolizuje tę liczbę w Starym Testamencie. Opowiada też dalej, że gdy

4 Scriptores rerum Prussicarum, t. 3, ed. E. Strehlke, Leipzig 1866, s. 439-441 (z rękopisu Biblioteki Kónnickiej 52, f. 148v n.).

5 F. Piekosiński, Wybór znaków wodnych $z X V$ stulecia, Kraków 1896, nr 1075 (r. 1470). 
apostołowie postanowili rozejść się na cały świat, przybyli do Jerozolimy, do Jakuba Młodszego, którego nazywa biskupem, i złożyli mu relacje z tego, co zdziałali i jakie uczynili cuda. Dopiero potem wyruszyli każdy w inną stronę. Piotr udał się do Italii, Paweł do Grecji, tj. do Rusinów i jakby na cały świat. (Mówiąc o Rusinach, być może miał autor na myśli prawosławnych). Tak po kolei wymienia wszystkich apostołów, zaznaczając gdzie prowadzili działalność apostolską. Przed rozejściem się, aby byli zgodni w nauczaniu prawd wiary, ułożyli Skład apostolski. Piotr powiedział: „Wierzę w jednego Boga Stworzyciela nieba i ziemi”. Następuje potem krótka nota o świętym Tomaszu apostole, po czym kaznodzieja powraca do wykładu Składu apostolskiego. Przypisując jego poszczególne artykuły apostołom, autor zaczyna znowu od św. Piotra. Mówi, kto w Starym Testamencie przepowiedział daną prawdę wiary, a następnie daje krótki jej wykład. Ostatni artykuł do Credo miał dodać Maciej, mówiąc: „Ciała zmartwychwstanie, żywot wieczny Amen”. I tak, zdaniem kaznodziei, wyznanie wiary poszczególnych apostołów miały złożyć się na ten podstawowy tekst $w$ nauczaniu religijnym, choć wiadomo, że powstał on dopiero w II wieku ?

Drugie kazanie, publikowane poniżej, to rękopis B 23 Biblioteki OO. Paulinów na Skałce w Krakowie; pochodzi on z końca XV w. Jego główną część (s. 20-298) stanowi kolekcja kazań de sanctis zwana Thesaurus novus. W pozostałej części znajdują się kazania o Najświętszej Maryi Pannie i o świętych. Autor tych kazań jest nie znany, choć był nim prawdopodobnie Polak. Powołuje się on np. na Mikołaja Kozłowskiego, profesora teologii Uniwersytetu Krakowskiego, zmarłego w r. 1443 (s. 400), wspomina kleryka Anzelma Przeszaka (s. 396). Na s. 461—472 znajdują się trzy kazania na Rozesłanie apostołów, mające te same verba thematis: "Convocatis Ihesus XII apostolis suis". Wskutek wyrwania trzech kart w pierwszym kazaniu brak zakończenia, a w drugim początku. Omawiam i wydaję drukiem pierwszy tekst, ponieważ tylko w nim znalazło się wspomnienie o Jagielle i bitwie pod Grunwaldem.

$\mathrm{Na}$ początku kazania autor stwierdza, że ewangelia mówi o rozesłaniu apostołów przez Chrystusa, aby głosili słowo Boże całemu światu, a szczególnie poganom, którzy nie znają prawdziwego Boga i czczą bożki. Kaznodzieja porusza trzy zagadnienia: powołanie apostołów, nadanie im władzy i rozesłanie. Apostołów symbolizuje dwanaście bram, po trzy z każdej strony świata. Przez nie dochodzi się do jednej wiary. Chrystus dał apostołom władzę nad demonami oraz moc czynienia znaków i cudów. Także i ten autor twierdzi, że znaki i cuda były potrzebne w czasach

- J. Wolny, Tematy $z$ nauczania religijnego $w$ pierwszym akresie chrystianizacji Polski, [w:] Częstochowskie studia teologiczne, Częstochowa 1973, s. 193; tenże, Z dziejów katechezy, jw. s. 192. 
Chrystusa i apostołów, bo wiara była jak nowo narodzone dziecię. Gdy zaś została umocniona męką Chrystusa, apostołów i świętych, znaki przestały być potrzebne. Jako przykład podaje uprawę kapusty, którą trzeba podlewać tak długo, dopóki nie podrośnie. W obecnych czasach, mówi kaznodzieja, wiara i Kościół obywają się bez cudów. Konieczne jest natomiast praktykowanie cnót, pobożności, gdyż o prawdziwej wierze świadczy święte życie, mowa nieskazitelna etc. Zresztą wiara tych, co nie widzieli a uwierzyli jest silniejsza niż tych, którzy, aby uwierzyć, potrzebują znaków. Te potrzebne są niewiernym, tj. Saracenom, Turkom, Rusinom. W dalszym ciągu kaznodzieja mówi o podwójnym posłaniu apostołów: najpierw do Żydów, a potem dopiero do pogan. Ostrzeżenie Chrystusa, że lepiej będzie Sodomie i Gomorze niż tym, co nie przyjmą apostołów, odnosi autor do chrześcijan, którzy nie chcą słuchać słowa Bożego. Od jednego grzechu przechodzą oni do drugiego i stają się z dnia na dzień gorsi zamiast postępować w cnotach i stawać się lepszymi. Kaznodzieja przypomina, że Chrystus posłał na świat dwunastu apostołów, aby czynili pokój między ludźmi a Bogiem, między poszczególnymi królestwami, między sąsiadami. Z kolei przechodzi do sprawy pokoju, który przez wiele lat był zachowywany pomiędzy Krzyżakami i Polska, podobnie jak między Sennacheribem, królem asyryjskim, i Ezechielem, królem judzkim. Na tle tej historii biblijnej, opisanej w czwartej księdze Królewskiej (rozdz. 18-19), kaznodzieja przedstawił konflikt krzyżacko-polski, porównując Jagiełłę z Ezechielem, a wielkiego mistrza krzyżackiego z Sennacheribem. Ezechiel mądrze rządził Izraelem. Postrącał bożki i połamał sporządzonego przez Mojżesza węża miedzianego, który potem stał się przedmiotem bałwochwalstwa. Jednakże król asyryjski Sennacherib nie chciał utrzymać pokoju z Ezechielem. Posłał więc z poselstwem Rapsaka, a ten przemawiał drwiąco do Ezechiela. Wówczas Ezechiel modlił się gorąco. Pan go wysłuchał i dał mu zwycięstwo. Posłał bowiem anioła, który w nocy, w obozie zabił 185 tysięcy Asyryjczyków. Sennacherib przerażony zbiegł do Niniwy, gdzie został zabity przez dwóch swoich synów. Podobnie było z Jagiełłą i Krzyżakami. Król zniszczył bowiem bożki pogańskie i powycinał gaje czczone na Litwie i cały naród litewski przyprowadził do Kościoła katolickiego. Wielki mistrz nie chciał jednak przestrzegać z nim układów pokojowych, zawartych przed laty. Zajął liczne miasta, zgarniał łupy i jeńców, w tym także kobiety i panny, narażając je na utratę czci. Ogniem i mieczem pustoszył kraj, wyciskając wszędzie łzy, jak podaje Cronica Polonorum. Wreszcie wielki mistrz krzyżacki zebrał wielką armię złożoną z ludzi mówiących językiem niemieckim i napadł na Polskę, aby zgubić króla i cały jego naród. Do Jagiełły wysłał posłów, którzy ofiarowali mu dwa miecze: jeden dla króla, a drugi dla jego brata Aleksandra Witolda, drwiąc przy tym, że 
wielki mistrz czyni to dlatego, bo wie, że Polska cierpi na niedostatek broni. Jagiełło przyjął pokornie owe miecze, ratunku zaś szukał u samego Boga. Przed bitwą bowiem modlił się gorąco w kaplicy przed ołtarzem i płakał, mówiąc do Boga: Ty wiesz, że nie pokładam nadziei ani w bitwie, ani w armii tylko w Tobie, który dzisiaj rozesłałeś apostołów, aby pokój czynili. Patrz, jak wrogowie nastają na rozlanie krwi chrześcijańskiej. Bóg za przyczyną świętych apostołów wysłuchał modlitwę Jagiełły i dał mu zwycięstwo. Na polu bitwy padło 130 tysięcy zbrojnych, wielu przerażonych dostało się do niewoli. Wielki mistrz, widząc klęskę, zbiegł $\mathrm{z}$ pola bitwy do lasu i tam zginął $\mathrm{z}$ ręki nawet nie rycerza, ale jakiegoś sługi. Zwycięski król ze zdobytymi łupami, wojskiem i jeńcami przybył do Krakowa. Składając zaś Bogu dzięki za zwycięstwo, zawiesił na tę pamiątkę w katedrze krakowskiej zdobyte chorągwie krzyżackie. Za otrzymane dary Królestwo Polskie powinno więc dziękować Bogu i czcić świętych apostołów za ich wstawiennictwo.

Omówione kazania nie przynoszą nowych szczegółów do konfliktu krzyżacko-polskiego i bitwy pod Grunwaldem. Mówią raczej ogólnie o tym wielkim wydarzeniu historycznym, nie wymieniając nazwy bitwy. Powtarzają fakty znane $\mathrm{z}$ dzieła Jana Długosza i $\mathrm{z}$ innych piętnastowiecznych źródeł, zwłaszcza te owiane legendą. Działają na wyobraźñię słuchaczy, podkreślając wielką liczbę poległych. Stojąc na stanowisku religijnym zwycięstwo Jagiełły tłumaczą obaj autorzy interwencją Boską. Porównują go z bohaterami biblijnymi i świętymi. Niemniej podobnie jak okolicznościowa poezja łacińska i polska ,o wielkim pobiciu” ", oddziaływały one również na kształtowanie i ugruntowanie świadomości narodowej, na umacnianie pamięci o przeszłości $\mathrm{w}$ niższych warstwach społecznych, do których łatwo docierało słowo kaznodziei. Dzięki corocznym rocznicom grunwaldzkim, obchodzonym 15 lipca, przenikały do świadomości społecznej i utrwalały się w niej fakty z historii Polski. Pamięć o tym największym zwycięstwie oręża polskiego w XV w. budziła poczucie wspólnoty narodowej, solidarności i dumy, zwłaszcza że tak ostro i wyraźnie podkreślano narodowościowe tło konfliktu, odwieczny antagonizm niemiecko-polski. Tworzył się dzięki temu kult przeszłości oraz osoby Władysława Jagiełły, założyciela panującej w Polsce w XV w. dynastii ${ }^{7 \mathrm{a}}$.

O pamięć Władysława Jagiełły swojego fundatora i odnowiciela, szczególnie dbał Uniwersytet Krakowski. Problem antagonizmu krzyżacko-polskiego pojawił się np. w kazaniu de sancto Briccio na temat „Ecce sacerdos magnus", które wygłosił 13 XI 1410 na mszy św. uniwersyteckiej

7 C. Ochałówna, Bitwa grunwaldzka w poezji polsko-łacińskiej XV w., „Małopolskie Studia Historyczne” 3 (1960) z. $1-2$ s. 81-106.

$7 \mathrm{a}$ Zob. T. Lalik, O patriotycznym święcie Rozestania Apostołów w Małopolsce w XV w., „Studia Źródłoznaweze” 26 (1981) s. 23-32. 
świeżo promowany bakałarz teologii Łukasz z Wielkiego Koźmina ${ }^{8}$. W następnym roku Jan z Kluczborka, również bakałarz teologii, wygłosił mowę na cześć króla Władysława Jagiełły z okazji zwycięstwa grunwaldzkiego ${ }^{9}$. W mowie na bakalaureat artium Kaspra Rokenberga ${ }^{10}$, wygłoszonej w r. 1420 przez nieznanego mistrza, wspomniana jest np. jako wzór abstynencja Jagiełły od napojów alkoholowych, a Paweł z Worczyna w swoim komentarzu do Etyki Nikomachejskiej podniósł męstwo, jakim król odznaczył się w Prusach ${ }^{11}$.

Kultywowana pamięć o Grunwaldzie i czynach Jagiełły tak wrastała w świadomość społeczności uniwersyteckiej i w zbiorową pamięć o przeszłości, że to wielkie zwycięstwo oręża polskiego z czasem zrównało się z faktami historycznymi tej miary, co chrzest Polski i męczeńska śmierć św. Stanisława biskupa. Stwierdzić to można w pewnych zapiskach rocznikarskich. Natrafiłam na nie na marginesach inkunabułu 1108 Biblioteki Jagiellońskiej, zawierającego Supplementum cronicarum Jakuba Filipa Foresty z Bergamo, augustianina, zmarłego w r. 1520. Książka ta została wydana w Wenecji w r. $1490^{12}$. Należała ona do biblioteki Marcina Biema z Olkusza, profesora teologii Uniwersytetu Krakowskiego i astronoma (zmarł w r. 1540). Biem znany jest ze swoich historycznych zainteresowań, gdyż na marginesach efemeryd $z$ lat 1499-1531 zamieścił jakby dziennik, w którym systematycznie zapisywał, obok wiadomości o pogodzie, ważniejsze wydarzenia dotyczące Uniwersytetu Krakowskiego ${ }^{13}$.

W inkunabule 1108 Biem dopisał najważniejsze wydarzenia dotyczące panowania Władysława Jagiełły (chrzest, koronacja, odnowienie Uniwersytetu, Grunwald, śmierć) oraz jego królewskiej rodziny. Poprzedził je nielicznymi wiadomościami historycznymi. Zanotował np. urodziny św. Stanisława w r. 1030, jego męczeńską śmierć, a także dyspensę papieża Benedykta IX dla Kazimierza Odnowiciela, mnicha na zawarcie małżeństwa i koronację na króla Polski. Niewątpliwie widomości te były mu potrzebne do mów i kazań wygłaszanych w czasie różnych aktów uniwersyteckich, przede wszystkim aniwersarzy i wypominków.

${ }^{8}$ M. Kowalczyk, Mowy i kazania uniwersyteckie Łukasza $z$ Wielkiego Kozmina, „Biuletyn Biblioteki Jagiellońskiej” 12 (1960) s. 17-18.

$9 \mathrm{Z}$. Kozlowska-B udkow a, Uniwersytet Jagielloński $w$ dobie Grunwoldu, [w:] Zeszyty naukowe Uniwersytetu Jagiellońskiego 48, Kraków 1961, s. 55 n.; taż, Mowa mistrza Jana z Kluczborka na cześć króla Władystawa Jagielty, [w:] Mediaevalia. W 50 rocznice pracy naukowej Jana Dąrowskiego, Warszawa 1960 , s. $159-176$.

${ }_{10} \mathrm{M}$. Kowalczyk, Krakowskie mowy uniwersyteckie z pierwszej potowy XV w., Wrocław 1970, s. 74 .

11 J. Rebeta, Komentarz Pawta $z$ Worczyna do Etyki Nikomachijskiej, Wroclaw 1970 , s. 77 .

12 A. L e w i ka-Kamińska, Inkunabuty Biblioteki Jagiellońskiej, Kraków 1962, s. 106 (HC*2808).

${ }_{18}$ A. Birkenmajer, Biem Marcin, [w:] Polski słownik biograficzny 2 s. $68-69$. 
Omówione teksty publikuję w następującej kolejności:

I. Notabile de divisione apostolorum — rkps BJ przyb. 2/84 f. 94r-98r.

II. Sermo de divisione apostolorum - rkps Biblioteki OO. Paulinów na Skałce w Krakowie B 23 s. $461-472$.

III. Annotationes historicae Martini Biem - inc. BJ 1108 f. 181v, 184v, $226 \mathrm{v}, 228 \mathrm{v}, 232 \mathrm{v}, 240 \mathrm{r}, 241 \mathrm{v}, 243 \mathrm{r}, 244 \mathrm{v}, 245 \mathrm{v}, 249 \mathrm{r}$.

Tytuły tekstu II i III nie występują w cytowanych rękopisach, lecz zostały dodane przeze mnie ze względów edytorsko-formalnych. Dla tych samych powodów przyjęłam za tytuł początkową uwagę kopisty z I rękopisu.

NOTABILE DE DIVISIONE APOSTOLORUM

Notabile: De divisione apostolorum. Et potest fieri de sancto Thoma. Thoma, quia vidisti me, credidisti, beati qui 〈non〉 viderunt etc. (Ioan. 20, 29) Augustinus dicit: hodierna die, fratres karissimi, gaudere debemus, qui Divisionem apostolorum celebramus, quorum divisio est nostra colleccio. Divisi sunt per universum mundum ideo, ut in unam fidem omnes homines colligerentur. Ideo dies hodierna in omnibus ecclesiis debet celebrari, in qua pastores ad quas missi sunt, verbum salutis portare ceperunt in omnibus ecclesiis. Cum ascenderet Ihesus in celum missi sunt, hodie predicare profecti sunt. Non solum misit Christus XII apostolos ad predicandum sed eciam LXXII discipulos. Sed quia isti apostoli sunt principales eius discipuli et maiorem potestatem eis dedit Christus, ideo solum sanctum ewangelium de ipsis facit mencionem. Convocatis Ihesus XII discipulis, dedit eis potestatem miracula facienda cecos illuminare et alias infirmitates et demones effugare. Quia si signa non fecissent, tunc eorum eciam doctrinam homines non accepissent, cum eorum doctrina excedebat hominum racionem, ideo dedit eis potestatem signa facere, ut signis doctrinam confirmarent. Sed quare hodie predicatores talia signa non faciunt, respondet Gregorius: quia iam fides katholica est sufficienter approbata per Christi miracula et apostolorum, ideo non oportet ulterius hanc approbacionem renovare. Et sicut tunc Christus dederat (potestatem) apostolis miracula facere, sic et in hac die Christus 
per potestatem horum apostolorum magnum miraculum effecerat tempore magni belli in terra Prutenorum, cum monachi et Cruciferi linguam Polonicam volebant delere de mundo, quod per horum apostolorum virtutem dignatus est tueri nos et liberare de eorum manibus, [f. 94v] quando ipsos uti superbos dispersit Deus, nos ab eorum maliciis protegendo. Sed quare apostoli antea non fuerunt missi, licet ter divisi erant a Christo? Primo quando dixerat eis: In viam gencium ne eatis. Secundo erant divisi tempore passionis eius quando fugierunt ab eo. Tercio post ascensionem, quando predicaverant in Ierusalem et finibus eius. Sed ista trina divisio non fuit sufficiens, sicut ista quarta hodierna. Et ponit racionem Rababanus: non fuerunt divisi apostoli ita sufficienter, sicut hodie ideo, quia adhuc nondum erant illi, ad quos debuit eos Christus mittere. Similiter et Christus quando venit, plenitudo gracie et illi iam erant, ad quos Eum Pater debuit mittere, in hunc mundum dignatus est venire. Sic Christus apostolos suos inter Iudeos XII annis tenuit post suam in celum asscesionem, quia adhuc ex eis verbum salutis debebant recipere et converti ad Christum. Et post XII annum erant obstinati, ideo apostoli ad gentes sunt missi, quando dixerunt: Ecce convertimini ad gentes, qui XII egressi sunt. Duodenarius numerus apostolorum ponitur ad excludendum falsos apostolos, qui a tempore Christi inceperunt et apostolos Christi persecuti sunt, ut patet in Actis Apostolorum. Secunda causa est, quare iste numerus duodenarius apostolorum ponitur, quia in Sacra Scriptura mulitpliciter est figuratus. Primo per XII patriarchas, qui ex Jacob nati sunt. Jacob secundum Chrisostomum genuit XII apostolos non in carne sed in spiritu. Jacobus descendit cum suis XII filiis in Egyptum, ut multiplicarentur, sic Christus cum suis XII apostolis descendit in mundum et multiplicatus est per mundum per ipsorum divisionem, Christianum populum generando. Alias causas obmitto causa brevitatis. [f. 95r] Inter hos XII apostolos duo discipuli hoc nomine Iudas sunt vocati, per quos omnes Christiani designatur. Primo per Iudam Iacobi illi, qui in confessione fidei perseverant. $2^{\circ}$ per Iudam $\langle\mathrm{I}\rangle$ scarioth illi, qui relicta fide per mala opera retro ad damnacionem convertuntur. Et cum voluerunt se dividere, venerunt omnes ad Ierusalem ad episcopum suum ad Jacobum Minorem, cui narrabant, quomodo Deus omnipotens per eos multa bona fecerat, que miracula. Sanctus Iacobus iterum in magna sollempnitate narrabat populo et tunc post hoc fecerunt inter se divisionem. Petrus ivit in Ytaliam, Paulus in Greciam, id est ad Ruthenos et quasi in totum mundum, Iohannes in Azyam, Thomas in Iudeam et postea in Indiam, Andreas in Achayam, Philipus in Frigiam, Bartolomaeus in Ciliciam, Matheus in Ethiopiam, Iacobus in Hyspaniam, Symon in Persidiam, Thadeus Madeus in Mezopotaniam, Matheus in Palestinam, Lucas in Bytiniam, Marcus in Allexandriam. Sed quando voluerunt dividi, ut essent 
concordes in sua predicacione, prius consilium habuerunt, quid predicarent. Et sic consiliantes inter se invenerunt unum sermonem optimum, quem predicarent. Qui sermo habet XII capitula in se, seu XII articulos fidei. Primum articulum componit Petrus, dicens: hoc predicabo: Credo in Deum patrem omnipotentem etc. Vide hunc sermonem hoc modo, quia istam introductionem feci de divisione apostolorum, videlicet de sancto Thoma.

Viderunt et crederunt, Ioh. $\mathrm{XX}^{\circ}$ [29]. Credere resureccionem Christi est de necessitate salutis, sed beatus Thomas apostolus Christi cum alii apostoli dixissent sibi: Vidimus [f. 95v] qui resurexit a mortuis, noluit credere, sed dixit: $\mathrm{Ni}\langle\mathrm{si}\rangle$ videro in manibus eius fixuram clavorum et mittam digittum meum in latus eius, non credam. Et Ihesus Christus nolens suum apostolum habere incredulum sed fidelem ostendit ei cicatrices vulnerum suorum dicens: Thoma, vide manus meas et pedes meos et extende manum tuam et mitte in latus meum et noli esse incredulus sed fidelis. Respondit Thomas et dixit: Dominus meus et Deus meus Dixit ei Ihesus: Quia vidisti me Thoma. Que fuerunt verba loco thematis posita etc. [Ioan. 20, 25-29] In quibus verbis letificat nos Dominus esse beatos per fidem, dum dixit: Beati qui non viderunt et crediderunt. Nec tamen sine fide potest quis salvari. Sicut de hoc dicit Apostolus ad Hebreos XI [6] Sine fide impossibile est placere Deo. Et Ihesus dicit Marc. ultimo [16, 16] Qui crediderit et baptizatus fuerit, salvus erit et qui non crediderit condempnabitur. Ideo necessarium est, ut credamus in Deum. Est differencia inter credere Deum et credere Deo et credere in Deum. Credere Deum est credere, quod ipse sit Deus. Sic et demones credunt et contremescunt. Iacobi primo [2, 19]. Credere Deo est credere vera esse que Deus loquitur. Et sic eciam mali credunt. Sed credere in Deum est credendo Deum amare et per amorem ei inherere, quod soli boni faciunt et credunt. Et ideo qui dicit se credere, mentitur, si non diligit Ipsum. Nota sed ut sciamus, quomodo debeamus in Deum credere, positi sunt nobis XII articuli fidei per XII apostolos Christi prout habentur in Simbolo, quod dicitur proprie collectio sermonum. Ideo Innocencius papa dicit, quod postquam apostoli Spiritum Sanctum acceperunt, conferentes in Ierusalem XII articulos fidei statuerunt, quod Simbolum vocatur. Et unusquisque eorum bolum, id est particulam [f. 96r] suam adiecit. Primum articulum posuit primo Petrus dicens: Credo in Deum Patrem, Omnipotentem, creatorem celi et terre. Ex quo possumus intelligere, quod Deus nos vult salvare, quia est pater noster et pater non potest obliviscere filios suos. Eciam potest salvare, quia est omnipotens, cui nulla potestas potest se opponere. Item scit nos salvare, quia scivit celum et terram sapienter creare. Hoc eciam predixerit Ieremias dicens: Patrem invocabitis, qui fecit celum et terram. 
Et Gen. [1,1]: In principio Deus creavit celum etc. Secundum articulum composuit Andreas. Et in Ihesum Christum filium eius unicum Dominum nostrum. Et istud predixerat David [Ps. 2,7] dicens: Dominus dixit ad me, filius meus es tu. Et sic debemus credere, quod Christus licet sit filius David, tamen est coequalis Patri et eternus secundum divinitatem Ioan. $X$ [30]: Ego et Pater unum sumus, scilicet secundum formam Dei, sed secundum formam servi hominis maior est Pater Christo. Tercium articulum posuit Iohannes. Qui conceptus est de Spiritu Sancto, natus ex Maria virgine. Et hoc predixerat propheta Is. VII [14] Ecce virgo concipiet et pariet filium, per quod innuitur quod non tantum est natus sine omni pecato sed eciam conceptus quia de Spiritu Sancto, Luc. $I^{\circ}$ [35] Dixit angelus Marie: Spiritus Sanctus superveniet in te et virtus Altissimi etc. Non sanctificatus in utero sicut Iohannes et alii sancti, sed matrem conservans in plenitudine sanctitatis et castitatis, quia virgo fuit ante partum et eciam post partum etc. Quartum articulum posuit Iacobus Zabedei. Passus sub Poncio Pilato, crucifixus, mortuus et sepultus, ut nos a morte liberaret. Et ideo assimilatur [f. 96v] fenici, que est unica avis in mundo, que dum senescit, in ignem sibi paratum sponte se proiecit et $3^{a}$ die de eius cinere novus fenix resurgit vel eciam assimilatur pellicano cui dum serpens pullos occidit sed ipse se rostro in pectore vulnerat et pulli eius sanguine aspersi resurgunt et ipse moritur. Sic Christus nos a serpente infernali protexit et mortuos suo sanguine resuscitat etc. Quintum articulum posuit Thomas dicens: Descendit ad inferna. Hoc eciam predixit Ozeas XVIII [13,14] O mors, ero mors tua. Voluit Christus descendere ad inferna, ut vivificaret et letificaret captivos et eos de captivitate liberaret. Zach. IX ${ }^{\circ}$ [11] Et tu in sanguine testamenti emisisti vinctos de lacu, in quo non erat aqua. Et nos debemus eciam in infernum purgatorii descendere et visitare ac letificare illos qui sunt in purgatorio et subvenire oracionibus, ieiuniis et elemosinis et messis senctis etc. Sextum articulum posuit Bartholomeus dicens: Tercia die resurexit a mortuis. Huius figura erat in Iona propheta, qui fuit tribus diebus et tribus noctibus in ventre piscis, ut habetur eiusdem II $^{\circ}$ [1] et Math. XII [40] Sicut fuit Ionas in ventre ceti tribus diebus et tribus noctis sic erit Filius hominis in corde terre tribus diebus et tribus noctibus. Resurexit autem, ut nos doceret resurgere hic per graciam de pecato ad iusticiam Ad Rom. XVI [6,4] Quomodo Christus resurexit a mortuis per gloriam Patris ita et nos in novitate vite ambulemus. Postea in futuro per gloriam resurgemus Ad Rom. VIII ${ }^{\circ}$ [11] Qui suscitavit Ihesum Christum a mortuis vivificabit mortalia [f. 97r] corpora nostra. Et resurexit Christus cum certis signis. Sic et nos debemus resurgere. Septimum articulum posuit Philipus: Ascendit ad celos, sedet ad dexteram Dei Patris omnipotentis. Et hoc predixit Amos IX ${ }^{\circ}[6]$ Qui edificavit ascensionem suam in celum, et ascendit 
in iubilacione. Et dominus etc. Ascendit quidem ad celos, ut nobis ianuam celestem apperiret Ad Ebreos IX $^{\circ}$ [12] Per proprium sanguinem introivit semel in sancta eterna redemcione inventa. Ascendit eciam, ut nobis viam ostenderet, ut nos secum duceret. Mich. II $^{\circ}$ [13] Ascendit iter pandens nobis. Ascendit ut pro nobis interpellaret Patrem. Hebr. IX ${ }^{\circ}$ etc. Octavum articulum posuit Matheus dicens: Inde venturus est iudicare vivos et mortuos. Hoc predixit Zophonias III ${ }^{\circ}$ [8] Expecta dicit Dominus in futurum, quia iudicium meum est, ut congregem gentes et collocem regna. Veniet Christus ad iudicium, ut iudicet iuste, qui hic iudicatus est iniuste. Ad cuius adventum, ut dicit Anastasius in suo Credo, habent omnes homines resurgere cum corporibus suis et redituri sunt racionem de factis propriis, que his fecerunt. Et non tantum de factis, sed eciam de verbis ociosis. Et quod tunc erit de turpibus et de omnibus cogitacionibus, quomodocumque sunt oculte Eccl. XII [14] Cuncta que sunt sub celo adducet Dominus ad iudicium etc. Nonum articulum ponit Iacobus Alphei seu Minor dicens: Credo in Spiritum Sanctum. Hoc predixit Iohel II [28] dicens: Effundam Spiritum meum super omnem carnem et prophetabunt filii vestri et filie. Et sicut in Patrem et Filium sicut in [f. 97v] Spiritum Sanctum credere oportet, cum Spiritus Sanctus Patri et Filio est consubstancialis et coeternus et utroque procedit eternaliter. Sic eciam procedit in nos Spiritus Sanctus cottidie spiritualiter, si in dileccione eius manemus et mandata eius servamus Ioh. XIII ${ }^{\circ}$ [16] Si diligitis me, mandata mea servate et ego rogabo, Patrem, ut alium Paraclitum dabit vobis, ut maneat vobiscum in eternum, quem mundus non potest capere etc. Decimum articulum posuit Simon dicens: Sanctam ecclesiam katholicam Hoc eciam predixit Micheas: Invocabunt omnes Deum et servient ei. Et ecclesia dicitur congregacio fidelium in una fide et in uno baptismo. Et ideo Apostolus ait ad Thimotheum IIII ${ }^{\text {to }}$ [Ad Ephes. 4, 5] Unus Deus, una fides et unum baptisma, quoniam credere debemus quod sit ecclesia id est congregacio fidelium, in qua debemus manere in caritate Dei et amore mutuo. Ioh. XVII ${ }^{\circ}$ [1] Volo, ut unum sitis sicut ego et Pater unum sumus. Ex quo patet, quod nullus debet abici vel excomunicari ab ecclesia, quia extra eam non est salus, sicut extra archam Noe nullus salus fieri potuit etc. Undecimum articulum posuit Thadeus dicens: Sanctorum communionem, remissionem pecatorum. Et hoc eciam predixit propheta dicens [Ps. 102,3] Qui propiciatur omnibus iniquitatibus tuis. Et credere debemus, quod in ecclesia fit comunicacio iuxta illud Ps. [118, 63] Particeps ego sum omnium timencium te et custodiencium etc. Existens in pecato mortali fit particeps omnium bonorum operum, que fuerunt seu aguntur in ecclesia. Et remissio omnium peccatorum, quam credere debemus, fit in ecclesia per baptismum, per penitenciam et per alia sacramenta. [f. 98r] Et secundum Ambrosium pecatum aut donatur, aut dele- 
tur, aut tegitur. Donatur per graciam, deletur per sanguinem et tegitur per caritatem. De primo Luc. $\mathrm{II}^{\circ}[7,42]$ Non habentibus illis unde redderent donavit utrisque, id est permisit. De secundo Apoc. $I^{\circ}$ [5] Lavavit nos a pecatis nostris in sanguine suo. De tercio Prov. $X$ [12] Universa delicta operit caritas. Duodecimum articulum posuit Mathias dicens: Carnis resureccionem et vitam eternam. Amen. Hoc eciam predixit Iob dicens: Credo quod redemptor meus vivit et in novissima die de terra $\langle$ re $\rangle$ surecturus sum. Credere enim debemus, quod omnes resurgere debent in corporibus suis, sed differenter mali ad mortem eternam et boni ad vitam eternam, sicut de hoc dicit Anastasius in suo Credo, quod qui bona egerunt ibunt in vitam eternam, sed qui mala ibunt in ignem eternum. Et hoc est fides katholica, quam nisi quisque fideliter firmiterque crediderit, salvus esse non poterit. Et ideo qui eum viderunt et crederunt, quam beatitudinem consequentur cum sancto Thoma apostolo, qui dicitur Didimus, cuius vitam sic breviter auditis.

II

\section{SERMO DE DIVISIONE APOSTOLORUM}

Convocatis Ihesus XII discipulis suis etc. Luce IX $^{\circ}$ [1]. Hoc ewangelium facit mencionem de divisione XII apostolorum, qui a Christo erant missi ad predicandum verbum Dei toti universo et precipue gentibus, qui Deum non noverant aut propter culturam ydolorum; Marc. ultimo [16, 15]: Euntes in [p. 462] mundum universum predicate ewangelium omni creature id est homini, qui participat cum omni creatura in a $\langle$ li $\rangle$ quo. Sed sicut videmus, si aliquis cupit bonum semen seminare, ut sibi fructum bonum afferat, oportet quod omnia impedimenta excludat et exclusis tenetur disponere terram per araturam et tunc primo debet seminare, sed quia verbum Dei est semen, ad quod seminandum Filius Dei venit Mat. XIII ${ }^{\circ}$ et inde misit XII apostolos ad seminandum verbum Dei, nam nemo potest producere fructum salutis eterne nisi de terra cordis humani eiciantur spine avaricie, que suffocant semen verbi Dei, allappe luxurie que valde faciunt adherere carnalibus et instabilitatem procurant, urtice perfidie, que nimis confortant hominem in pecatis, petre duricie que 
faciunt arescere semen, cum non habuit humorem, et semotis istis impeditis tunc quilibet cor suum debet disponere ad credendum. Sed quomodo credant, cum non audiunt, cum fides sit ex auditu, et quomodo adiscant sine predicatore. Ideo Ihesus Christus volens, ut verbum ewangelii a se predicatum et seminatum in cordibus hominum facere $\langle t\rangle$ fructum, elegit XII predicatores, qui errores et vicia extirparent virtutes plantarent, de quibus dicit nobis hoc ewangelium, quod de tribus nos docet: primo de convocacione apostolorum, secundo de potestate eis tradita, tercio de divisione eorum. Primum notat altam vocacionem eorum qui sunt vocati ad supernos status non tantum mundi sed et celi, quia ad seraphicum. Secundum notat eius potestatem, quam eis contulit super omnia demonia. Tercium notat eorum officium, ad quod sunt vocati, quia ad predicandum verbum Dei. Dixi primo de convocacione [p. 463] apostolorum, qua convocavit eos simul ad se, ut eos mitteret ad predicandum, nam triplex eorum fuit vocacio: prima ad agnicionem simplicem Christi, qua inceperunt credere in Christum propter quod secuti sunt eum et manserunt cum eo [Io. 10]; secunda fuit in familiaritatem, qua effecti sunt ei familiares; Luc. V: Omnibus relictis secuti sunt eum; tercia in appostolatum, quo fecit eos apostolos; Mat. IIII ${ }^{\circ}$ [22]: Illi autem relictis rethibus et patre secuti sunt eum. Hic autem vocavit eos simul ad explendam legacionem eius. Hic nos sumus vocati ter: Primo ad agnicionem fidei Christi ut discrete cognoscemus articulos fidei et hoc fit in baptismo; secundo ad familiaritatem eius et hoc quando nos admittunt ad Corpus Sanctum; tercio ad officium Christianitatis, quod debemus servare et vivere secundum illud et quicquid agimus in mundo nunquam debemus recedere a christianitate, sicut, ut apostoli recesserunt ab apostolatu. Videte ad appostolos, quales gradus sunt assecuti in istis vocacionibus. In prima vocacione placuit eis sermo Eius; in $2^{a}$ vocacione placuit eis Christi sancta conversacio, qua ducebat eos ad virtutes; in $3^{a}$ placuerunt eis eius miracula, que faciebat, propter que omnino ei adheserunt. Si autem placuerint nobis ista tria, que apostolis placuerunt, nunquam tam turpiter viveremus sicut vivimus, ut recederémus a Christo, sed quia nec sermo Christi, nec conversacio sancta, nec miracula placent nobis, ideo turpiter vivimus et adhuc peius quam pagani. Nam melius et pecatum cavere et non committere, quam amissum emendare. Facilius enim hosti possumus resistere, a quo nondum victi sumus, quam ei, a quo iam superati ac devicti cognoscamur.

$\mathrm{S}\langle$ ed $\rangle$ dicit, quare convocavit tantum XII, quos [p. 464] nominavit apostolos. Dicitur, quod propter XII portas, per quas intratur ad fidem et de fide in regnum Dei et hoc secundum quatuor partes mundi. Nam hii apostoli primo erant tres porte ab oriente, quia populo apperiebant inteligenciam humane creacionis, humane redempcionis et humane regenera19 - Analecta Cracoviensia 
cionis per baptismum in tantum sciverunt de creacione, redempcione et regeneracione. Secundo erant tres porte ab austro, que apperiebant populo ardentem caritatem Christi, Eius incomprehensibilem claritatem et Eius inefabilem iocunditatem, et de istis veram noticiam habuerunt in austro. Tercio occasu erant tres porte, quia reserabant miserabilem fragilitatem et necessitatem peccandi horribilem deformitatem pecati et magnam frigiditatem ad bonum. Quarto ab aquilone erant tres porte, quia ipsi publicaverunt divini iudicii equitatem et pecatorum nostrorum condignam ulcionem et pene jehennalis eternitatem. Et per istas XII portas intelligimus XII apostolos. Populus a quatuor partibus mundi intrat in civitatem unitatis, scilicet in unitatem sancte fidei et baptismi. Dixi secundo de potestate eis tradita. Et hoc notatur cum dicitur: Et dedit eis virtutem et potestatem super omnia demonia. Nam virtus absque potestate malum est, quia inducit ad presumpcionem; potestas enim absque virtute debilis est et remissa. Ideo ista duo eis adiungit ut haberent virtutem, quantum ad sanandas infirmitates corporis, quia virtus tenet se ad corpus, sed potestas ad animam et ad demonia eicienda, ut sic totum hominem sanarent, quia totus homo periret, ideo dedit eis potestatem ad expulsionem demonum, quos enim [p. 465] demones ligabant, illi salvebant, quos demones excecabant, illi illuminabant, quos faciebant obmutescere, illi solvebant. Et magnum est quod dedit eis, scilicet potestatem super naciones demonum, qui naturaliter sunt potenciores hominibus et multum magis scientes quam homines. Et hec potestas apostolorum erat valde gloriosa, quia reformabant, que demones destruebant. Demones inficiebant homines diversis infirmitatibus - ipsi sanabant, demones obsidebant homines - ipsi expellebant; Luc. $\mathrm{X}^{\mathrm{a}}[17]$ : Domine nobis eciam demonia subiciuntur in nomine tuo. Secundo habebant potestatem super omnes dracones serpentes et feras et aves que inimicantur homini propter pecatum primi hominis Luc. $\mathrm{X}^{\circ}$ [19] Ecce dedi vobis potestatem calcandi serpentes et scorpiones et super omnem virtutem inimici et nichil vobis nocebunt. Tercio dedit eis potestatem super omnem creaturam corporalem. Ideo mutabant lapides in gemmas, in aurum et poterant ignem descendere facere de celo (Math. $\mathrm{XI}^{\circ}$ ). Quarto Christus in eorum factis assistebat sicut eis promittebat; Math. ultimo [28, 20]: Ego vobiscum sum usque in consummacionem seculi. Et angeli cum eis loquebantur, eos conducebant et eos custodiebant. Quinto dedit eis potestatem super omnes infirmos et infirmitates eorum ut eos sanarent aliqui per imposicionem manuum; Marc. ultimo [16,18]: Super egros manus imponent et bene habebunt. Alii modo deprecativo ut Iohannes suscitavit Drusianam, aliquo modo deprecativo ut Petrus suscitavit Thabitam viduam. Nam, ut dicit Isidorus libro capitulo $\mathrm{XV}^{\circ}$ De sanctorum miraculis, Christus sermonem apostolorum duplici testimonio probabat: primo testimonio, vite sancte exem- 
plo, quam didicerant a Christo que consistebant in sex. Primo in virtute profunde humilitatis [p. 466]; secundo voluntarie paupertatis racione cuius omnia derelinquerunt; $3^{\circ}$ mire castitatis tam in anima quam in corpore; quarto ferventis caritatis, propter quam nemo potuit eos separare a Christo neque pena neque morte; quinto continue asperitatis, quam servabant usque ad mortem. Attendentes illud Math. VII ${ }^{\circ}$ [13] Quam lata est via, que ducit ad perdicionem et multi vadunt per eam sed via que ducit ad vitam est angusta et arta et pauci eam invenerunt; sexto alte firmitatis in permanencia fidei et in paciencia adversitatis. Et istis virtutibus plures converterunt ad fidem quam signis. Et hoc eciam dicit Gregorius: Cuius vita despicitur, restat ut sermo eius condempnatur. Secundo testimonio miraculorum et signorum que operabantur pro confirmacione et nutricione fidei que tempore Christi et apostolorum fuit tanquam infans nutritur lacte et mollibus cibis ut posset consolidari, sic fides nutriebatur acsi lacte et cibo molli, ut posset consolidari in cordibus hominum. Et sic valde plantative crescebat et consolidabatur acsi pueri. Sed cum est confirmata passione Christi et apostolorum et aliorum sanctorum, que acsi infiniti occisi sunt pro confirmacione fidei et huic facto valde mirabantur reges, principes et alli pagani, qui videntes unum christianum occidi $\mathrm{X}$ alios convertebantur, alius quandoque milia, alius decem milia et hoc factum est, ut confirmaretur fides Christi in christianis. Et ex quo iam est bene confirmata, tunc iam est ablactata, sicut puer qui iam solidatus est in membris et est fortis in eis, amplius non datur ei lac neque cibus mollis sed fortis; et tunc dicitur ablactatus. Sic et caules tam diu rigantur, quousque non adolent et cum adoleverint amplius non rigantur. Iam [p. 467] ergo fides et ecclesia christianorum non indiget signis et miraculis, a quibus cum sit ablactata sufficienter, sed indiget virtutibus claris, ut castitate, devocione, iusticia, temperancia, vita sancta et conversacione munda. Si autem aliqui desiderant miracula fieri in ecclesia sancta non [in $\mathrm{ms}$. omne] autem in corde suo. Si aliqui de celis descendent aut ex mortuis surgent et dicent nobis de gaudiis regni celorum aut de penis inferni quales sunt et quam dure, ut exemplum, fides in nobis firmaretur bene aut audientes talia bene operarentur. Respondetur: Si aliqui tales sunt inter nos, nichil faciunt aliud nisi quod desedant [!] verum testimonium, quod non habent fidem perfectam neque integram et talibus, si advenit aliqua adversitas aut temptacio statim cadunt a fide in pecata diversa. Dicit enim Simon de Cassia: Forcior est illorum, qui habent eam absque signis quam illorum qui habent eam cum signis, quia illi stant in ea firmiter nec se sinunt seducere neque pecatis infringere. Isti autem quam cito temptacio advenit aut adversitas, statim cadunt a fide. Et inde est quod aliquando una civitas, aliquando unum regnum cadit a fide. Si autem aliquis affectat corde aut 
dicit ore facere signa in ecclesia, talis querit vanam gloriam, ut laudaretur ab hominibus. Dicit enim apostolus I $^{\text {a }}$ Cor. XIIII ${ }^{\circ}$ [22]: Lingue in signum sunt 〈non〉 fidelibus sed infidelibus. Ecce iam signa et miracula non sunt necessaria christifidelibus, qui iam diu crediderunt, sed infidelibus et paganis, Sarracenis, Ruthenis et Turcis sunt signa necessaria, ut convertantur ad fidem et conversi ultra non querant signa nam Paulus apostolus volens convertere aliquos infideles ad fidem coram eis sanavit miraculose patrem infidelem Puplii Romani ab infirmitate febrium [p. 468]. Secundum Thimoteum infirmitatem non oracione neque signo aliquo sanavit sed medicina. Claudant ergo heretici ora eorum, ut dicit Albertus, qui dicunt quod papa et alii episcopi non haberent tantam potestatem quantam habuerant apostoli aut alii sancti viri, quia non operantur talia signa qualia illi. Dicitur eis, quia ibi ecclesia et fides novella indiguit nutrimento signorum, sed iam firmata sanguine Christi et apostolorum non indiguit talibus. Dixi tercio de missione XII apostolorum. Et hoc notatur cum dicitur: Et misit illos predicare regnum Dei et sanare infirmos, nam bina vice misit eos Christus. Prima missio eorum fuit ad Iudeos; Math. $\mathrm{X}^{\circ}$ [5]: In viam gencium ne abieritis et in civitates Samaritanorum non intrabitis. Et quia prope eos mittebat et ad domesticos, ideo prohibuit eis portare in via virgam, id est baculum, saccum, panem et pecuniam et duas tunicas. Et sic primum predicabant verbum Dei Iudeis. Secunda missio eorum fuit ad gentes et hoc quando fuerunt expulsi de Judaismo, de qua missione Mat. $\mathrm{X}^{\circ}$ [16]: Ecce ego mitto vos sicut oves in medio luporum. Estote ergo prudentes sicut serpentes et simplices sicut columbe. Et quia ad longam viam erant missi ideo admittit eis predicta portare, ut exemplum haberent aliquam consolacionem et hec mirabilis missio, quia solum XII mittit in totum mundum contra errores, contra scandala, contra ydola et pecata, et potuerunt dicere Christo: quid nos mittis XII ad homines tocius mundi et ipsi forte nos deglutina $\langle\mathrm{bu}\rangle \mathrm{nt}$ vivos. Et Christus potuisset eis respondere: Ego vobiscum sum usque ad consumacionem seculi, Mat. ultimo [28,20]. Quomodo enim prophete fuerunt dispersi inter gentes, sic eciam voluit descipulos esse dispersos qui pel[p. 469]lebantur de una civitate in aliam, de uno regno ad aliud et in quamcumque domum intrabant, plus dabant quam accipiebant, quia per eos Deus illi domui infundebat graciam. Ideo precepit eis: in quamcumque domum intraveritis, ibi manete [Mat. 10,11]. Quid domus nisi beneficium ecclesiasticum sicut dicit Rabanus super Ecclesiasticum, in quo debent manere edentes et comedentes, que apud ipsos sunt. Luc. $\mathrm{X}^{\circ}$ [7]. Et dicit: et inde non exeatis ad querendum delicias aut plura beneficia et tales solus Christus laudabat, dicens Mat. $\mathrm{XXV}^{\circ}$ [21]: Euge, serve bone et fidelis, quia in pauco fuisti fidelis, supra multa te constituam. Dicit Gregorius super Ezechielem: Fluvius, qui in multos rivos 
dividitur, cicius ab alveo desiccatur, sic talis gracia Dei privatur cicius, qui est divisus. Et sicut appostoli excusserunt pulverem de pedibus suis contra illos, qui fidem non receperunt et verbum eorum, sic hodie fidem non suscipientes aut fidem susceptam violantes variis pecatis aut erroribus excucientur in fine de medio fidelium ad medium demonum ut dicitur Mat. $X^{\circ}$ [14-15] Quicumque non receperit vos neque sermones vestros audierit exeuntes de domo aut de civitate excutite pulverem de pedibus vestris. Amen, dico vobis: Tollerabilius erit terre Sodomorum et Gomoreorum in die iudicii quam illi civitati. Hec maledictio Dei gravius super omnes infideles et Christianos non audientes verbum Dei, qui iam diu sumus christiani et utique ista maledictio vadit contra nos qui imus de pecato in pecatum, de uno in aliud et continue efficimur peyores; hodie mali sumus et cras peiores et post cras pessimi; hodie ebrius et cras magis ebrius et post cras aduc magis; hodie luxuriosus, cras aduc magis luxuriosus et sic absque statu. Sed e contra est de bonis, quibus dicitur [p. 470] Apok. XIIII ${ }^{\circ}[18,4-5]$. Exite de illa civitate, populus meus ut ne participes sitis delictorum eius, quoniam pecata eius pervenerunt usque ad celum. Hodie enim bonus cras vult esse melior et ultra cras optimus; hodie misericors cras misericordior. Hodie servit Deo et cras cogitat, quomodo melius serviret ei et non solum cras sed usque ad mortem; hodie castus et continue cogitat quomodo potest esse castior. Unde ergo ista divisio inter christianos ac si non eosdem sermones audirent et ac si non eandem escam manducarent, scilicet Corpus Christi. Nos vere sumus stulti, qui credimus eundem Salvatorem et non eundem iudicem expectamus. Videte, ad quod nos comparat, que ad illam panem quam Sodomam et Gomorram, que vive descenderunt ad infernum.

Videte quomodo Christus misit XII apostolos in mundum, ut facerent pacem inter homines et Deum, inter regnum et regnum, inter vicinos et vicinos. Quam eciam fecerant inter Prutenos et Polonos, qui multis annis stetit inter eos sicut inter regem Assiriorum Sennacherib et regem Ezechiam Israel IIII Reg. $10[18,13]$ et $\mathrm{XIX}^{\circ}$. Scilicet Sennacherib noluit tenere pacem cum rege Esechia, qui fecit omne bonum coram oculis Dei, qui confregit statuas ydolorum et confregit serpentem eneum, quem fecerat Moyses, propter ydolatriam, quam faciebant ei Iudei. Ita quod Sennacherib [in $m s .:$ sibi] non fuit similis cunctis regibus, sic magister Prussie noluit servare pacem cum Wladislao rege Polonie, qui de terra Lythphanie ydola et lucos et silvas excidit, quas colebant Lythphani, quos ad fidem Christi deduxit. Et sicut rex Sennacherib iam decem tribus captivaret [p. 471]. Sic magister Prussie multas civitates ceperat, multa spolia fecit et multas dominas et virgines captivavit ac dehonestavit, ubi non paucus fletus fuit et alias gladio et igne perimebat, ut in Cronica Polonorum docetur. Et sicut rex Sennacherib subiciens ei multos reges et regna circum- 
iacencia transiebat adversus regem Esechiam, sic magister Prussiae collectis multis linguis Theutunicorum ibat contra regem Poloniae volens deperdere eum cum sua gente. Et quem ad modum rex Sennacherib misit Rapacem cum valida manu ad regem Esechiam dicens ei: Hec dixit rex magnus Assyriorum: Que est fiducia ista, qua niteris rebellare regi magno Assyriorum. An speras in baculo arundineo atque confracto Egipto, super quem si incubuerit homo, cominutus ingredietur manus eius et perforabit eam? Et audiens hoc rex Esechias et receptis litteris scidit vestimenta sua et sacco indutus ingressus domum Dei expendit eas coram Domino et oravit dicens: Domine Deus Israel, qui sedes super Cherubin tu es solus Deus omnium regum. Tu fecisti celum et terram. Inclina aurem tuam et audi et apperi oculos tuos et vide, quomodo eciam Sennacherib misit, ut blasfemaret nomen Dei viventis et misit ad Isayam prophetam, quid deberet facere at ille ait: Ne timueris, quia Dominus pugnabit pro te; sic magister magnus Prussie cum forti manu misit nuncios ad regem Poloniae dicens hec: Dicit magister magnus Prussie. Audio quod cares gladiis, ideo mitto tibi duos gladios unum tibi, et alium fratri tuo Allexandro duci magno Lÿtphanie. Rex autem audito isto sermone et acceptis humiliter gladiis intravit oraculum et incepit orare, flere coram altari et orando [s. 472] dixit: Domine Ihesu Christe, nosce quod nullam spem pono in prelio isto et ne in armis, nisi in Te solo qui sicut hodie misisti XII apostolos in universum mundum, ut facerent pacem, in signum cuius dicebat eis Christus: In quacumque domum intraveritis dicetis: Pax huic domui Math. $\mathrm{X}^{\circ}[12]$, sic hodie mitte auxilium tuum, ut habeam regno pacem. Vide, Domine Ihesu Christe, quomodo instant in confusionem sanguinis Christianorum tuorum. Et sicut Deus exaudivit Ezechiam regem vel cum enim Sennacherib venit in Ierusalem ad capiendam eam cum magna potencia, tunc eadem nocte Deus misit angelum suum, qui interficit sibi de populo electo et armato CLXXXV milia et alii stabant immobiles sicut arbores, sic exaudivit regem Polonie, qui interfecit de populo electo Prutenorum CXXX milia et a $\langle c\rangle$ citos et alios cepit, qui pre nimio timore fixi stabant. Et sicut rex Sennacherib viso populo interfecto metdecimus evasit in civitatem Ninivem, ubi cum oravit in templo suos deos, duo filii venientes interfecerunt eum, sic magister Prussie viso populo interfecto evasit in silvam metdecimus ubi spuerveniens unus non rex nec nobilis nec dux aliquis sed unus servus interfecit eum securi. Et sicut rex Ezechias cum suo populo exiens exusserunt corpora illorum interfectorum, que erant redacta in cineres intactis armis et receptis armis et spolia multa reversi sunt in Iherusalem cum ingenti gaudio, sic rex Wladislaus cum populo suo receptis spoliis et armis et multis captivis et banderiis venit in civitatem Cracouiam cum magno gaudio. In cuius signum vir magne victorie gracias 
Deo agendo pependit banderia in ecclesia maiori in perpetuam rei memoriam. Propter hoc regnum illam reverenciam appostolis Christi tenetur exhibere pro beneficiis et impensis. Et si gra||

\section{III}

\section{ANNOTATIONES HISTORICAE MARTINI BIEM}

[f. 181v] S. Stanislaus Cracoviensis episcopus hoc anno VII kal. Augusti [26 VII] natus est, scilicet anno Christi 1030.

Iste Benedictus nonus dispensavit cum Kazimiro tercio rege Polonie in voto religionis et castitatis [anno 1032]. Cum enim fuisset monachus de regula sancti Benedicti et dyaconus, dispensavit cum eo et dedit sibi licenciam matrimonium contrahendi et ad regnum Polonie coronandi. Qui quidem rex strenuissimus fuit et restaurator a virtute nominatus.

[f. 184v] Sub hoc pontifice Gregorio septimo sanctus Stanislaus episcopus Cracoviensis per Boleslaum regem Polonie interfectus martirio coronatus est anno Domini 1079.

[f. 226v] Anno Domini 1386 illustrix [!] princeps Iahel magnus dux Lythwanie in regem Polonie est coronatus Cracovie in ecclesia cathedrali die dominica in crastino sancti Valentini [15 II], qui regnum cum fide suscepit et in baptismate Wladislaus est nominatus. Hic serenissimus princeps multa bona fecit. Quatuor uxores habuit: primam, serenissimam principem Hedvigim, ad cuius vota et instanciam Studium generale Cracovie dotando fundavit anno Domini 1400; aliam uxorem habuit Annam Celszka de Hvngaria; terciam nobilem Granowszka dictam; quartam inclitam principem Zophiam nominatam, de Moszkouia ducissam. Et ex hac generavit duos filios illustres principes, scilicet Wladislaum primogenitum et Andream iuniorem, qui postea Kazimirus est vocatus [alio tempore adscriptum:] Primogenitus post mortem patris regnavit Polonis. Post cuius interitum regnavit secundo genitus Casimirus annis 44. Qui mortus est anno Domini 1492 relictis post se filiis et filiabus multis. Nam post eum Ioannes Albertus senior regnavit Polonis annis 9. Quo mortuo regnavit Allexander annis quinque. Quo de medio sublato regnare cepit Sigismundus anno Domini 1507 et reliquit filium, qui natus est ei ex Bona regina ducissa Barri Napulie, Sigismundus nomine prima die Augusti anno Domini 1520.

[f. 228v] Hoc anno Christi, scilicet 1400, serenissimus Wladislaus rex Polonie fundavit et dotavit Studium generale Cracovie. Et eo anno per reverendissimum in Christo patrem dominum dictum Vysch Petrum episco- 
pum Cracoviensem utriusque iuris doctorem et cancellarium Studii eiusdem prima leccio in iure canonico ipso die sancte Marie Magdalene [20 VII] est facta. Et idem reverendissimus episcopus anno sequenti, scilicet 1401, in Quatuor temporibus post Exaltacionem sancte Crucis celebravit primum examen pro gradu baccalariatus in artibus.

[f. 232v] Hoc anno Christi, scilicet 1410 feria tercia in die Divisionis apostolorum [15 VII] serenissimus princeps Wladislaus rex Polonie cum illustri principe fratre suo Vitholdo magno duce Lȳtwanie in terra Pruthenorum in campo, qui dicitur Grinwalth, quod situm est prope Dąmbrowno conflictum magnum fecit cum Pruthenis. In quorum auxilium ex diversa pene Germania Almani convenerant volentes delere nomen et memoriam Polonorum. Unde Dei optimi maximi nutu actum est eorum id exigente superbia; totaliter prostrati sunt in centum et quadraginta milibus virorum armatorum, item septingentis quindecim, ubi magister generalis Cruciferorum cum marsalco occisi sunt. Et alii multi principes et domini interfecti; alii innumeri submersi; alii capti ita quod de captivis fuerunt prope 40 milia. Hec tanta Dei nutu victoria multis est memoranda seculis. De qua laus sit Deo omnipotenti per infinita secula. Amen.

[f. 240r] Isto tempore anno videlicet Domini 1434 inclitus serenissimusque princeps Wladislaus rex Polonie Lythwanus genere, qui prius Iahel nominatus erat, circa festum Penthecostes in Grodek opido Russie post multa preclara gesta post laudabiles plurimos victoriarum triumphos, cum regnasset 48 annis in Polonia feliciter, obiit, relictis duobus filiis ex inclita principe Zophia Moszkoviensi successores, videlicet Wladislaum postea regem Polonie et Hungarie et Kazimirum qui et ipse tandem regnavit in Polonia [adscriptum:] annis 44.

[f. 241v] Hoc tempore, anno videlicet Christi 1440 serenissimus Wladislaus Polonie rex iuvenis cum esset in artibus bellicis clarus et victoriis contra infideles Christi felicissimus ad regnum Hvngarie est accersitus, ubi gloriosus in victoriis contra Thurcos extitit. Qui et tandem post quatuor annos in bello seu prelio contra Thurcos pro Christi nomine occubuit.

[f. 243r] Nescitur tamen quid in rei veritate cum rege factum sit et nisi Hvngari cum Valachis ab eo fugissent victor in certamine extitisset. Hoc autem factum fuit in vigilia sancti Martini [10 XI; adscriptum:] Anno Domini 1444.

[f. 244v] Hoc tempore anno scilicet Domini 1448 Kazimirus Magnus dux Lithwanie filius Wladislai Magni regis Polonie coronatus est in regem Polonie circa festum sancti Iohannis Baptiste. Et regnavit feliciter in Polonia 44 annis, qui Prussiam et magistrum generalem Prussie perpetuo 
vinculo regno Polonie univit et subiecit, ut reges Polonie domini Russie sint et habeantur.

[f. 245v] Isto tempore anno Domini 1453 Iohannes de Capestrano vir religiosissimus et vite sancte, sancti Bernardini in predicacione imitator acerrimus venit Cracoviam, ubi sua predicacione multum in Dei populo monendo, castigando docendoque profecit. Venit autem Cracoviam in die Decollacionis sancti Iohannis Baptiste [29 VIII] et extunc bernardini in ligneis calceis incedentes in regno Polonie esse ceperunt.

[f. 249r] Hic erravit et defecit dicens Casimirum christianissimum regem esse hereticum. Quatuor. Wladislaus rex Hungarie et Bohemie fuit nepos Sigismundi imperatoris. Omnia hic male et false posuit et nihil in veritate hic scripsit de Casimiro Polonie rege christianissimo et de Wladislao Hvgarie et Bohemie rege. 